Kirja-arvio

\title{
Kertomuksen vaaroista ja funktioista
}

Mäkelä, Maria, Samuli Björninen, Ville Hämäläinen, Laura Karttunen, Matias Nurminen, Juha Raipola ja Tytti Rantanen (toim.). 2020. Kertomuksen vaarat: Kriittisiä ääniä tarinataloudessa. Helsinki: Vastapaino. 342 s.

Virtanen, Mikko T., Pirjo Hiidenmaa ja Jyrki Nummi (toim.). 2020. Kertomuksen keinoin: Tarinallisuus mediassa ja tietokirjallisuudessa. Helsinki: Gaudeamus. $364 \mathrm{~s}$

\section{Ulla Savolainen}

$\mathrm{M}$ aria Mäkelän johtama Tampereen yliopiston kirjallisuustieteilijöiden "Kertomuksen vaarat" -tutkimusprojekti on ollut epäilemättä yksi viime aikojen puhutuimmista humanistisista tutkimushankkeista. Tutkimuksen lisäksi hanke on saavuttanut huiman näkyvyyden niin sanotun suuren yleisön keskuudessa. Se on onnistunut ilmiömäisesti popularisoimaan kirjallisuudentutkimuksen näkökulmia ja nostamaan kertomuksen, sen toiminnan ja käytön sekä narratologisen analyysin mahdollisuudet näkyville ymmärrettävästi, kiehtovasti ja kriittisesti. Kertomuksen vaarat: Kriittisiä ääniä tarinataloudessa (2020) on tutkimusprojektin tutkijoiden, Maria Mäkelän, Samuli Björnisen, Ville Hämäläisen, Laura Karttusen, Matias Nurmisen, Juha Raipolan ja Tytti Rantasen kollektiivisesti toimittama tietokirja, "kertomuskriittinen opas" (s. 13), joka esittelee ja analysoi kertomuksen, kokemuksellisuuden sekä tarinallisuuden ilmentymiä ja käyttöjä mittavassa valikoimassa kompakteja tapaustutkimuksia ja näkökulmia.

Samoihin aikoihin Kertomuksen vaarat -kirjan kanssa ilmestyi myös toinen suomenkielinen artikkelikokoelma kertomusmuodosta ja tarinallisuudesta tiedonvälityksen kontekstissa. Mikko T. Virtasen, Pirjo Hiidenmaan ja Jyrki Nummen toimittamassa Kertomuksen keinoin: Tarinallisuus mediassa ja tietokirjallisuudessa -teoksen artikkeleissa tietokirjallisuutta ja journalismia käsitellään monipuolisista näkökulmista, jotka asettuvat väljästi kertomuksen ja kokemuksellisuuden kattokäsitteiden alle.

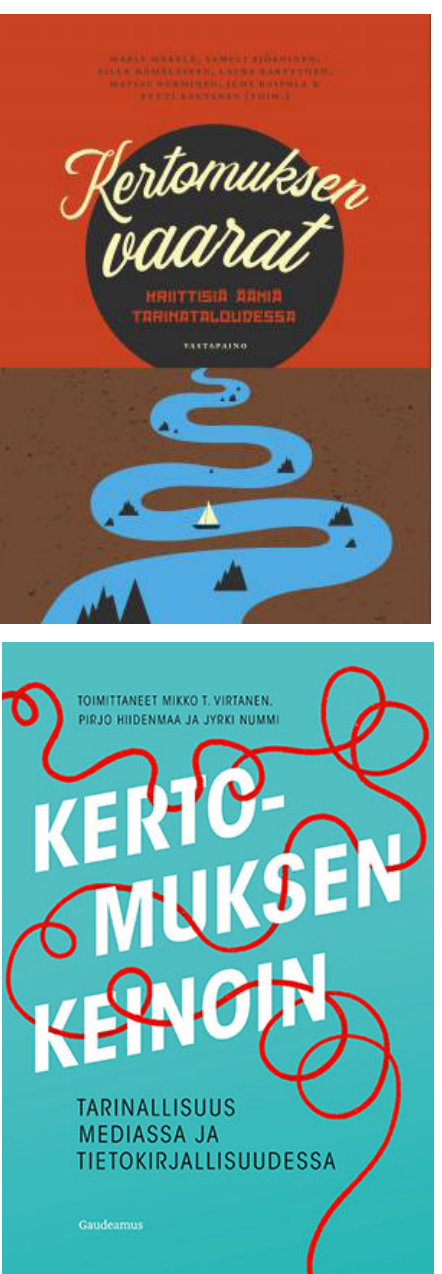


Kirjan kirjoittajat ovat kirjallisuuden- ja kielentutkijoita. Verrattuna opasmaiseen Kertomuksen vaarat -kirjaan, jonka artikkelit pyrkivät yleistajuisuuteen, Kertomuksen keinoin on klassisempi kokoelma tutkimusartikkeleita. Käsittelen tässä arviossa ensin Kertomuksen vaarat -teosta, sitten Kertomuksen keinoin -kirjaa ja lopuksi suhteutan niitä kevyesti toisiinsa.

\section{Analyysia, dialogia ja valistusta napakasti yhdistellen}

Kertomuksen vaarat tarkastelee kertomuksen käyttöä ja tarinallisuutta journalismin, sosiaalisen median, politiikan, aktivismin, radikalismin, mainonnan, yritysbrändäyksen, kaunokirjallisuuden, dokumenttielokuvan, ilmastonmuutosta koskevan tiedeviestinnän ja viranomaisviestinnän konteksteissa. Tutkijoiden kirjoittamien artikkeleiden lisäksi kirja sisältää eri tavoin kertomusten parissa työskentelevien ammattilaisten ja kokemusasiantuntijoiden näkökulmia, haastatteluartikkeleita, keskusteluja, kirjeenvaihtoa sekä avainkäsitteisiin pureutuvia tietolaatikoita. Mukana on kommentteja muun muassa toimittajilta, poliitikoilta, aktivisteilta, taiteen ammattilaisilta ja yrittäjiltä näyttelijä Antti Holmasta entiseen uusnatsijohtaja Esa Holappaan.

Kriittisen näkökulmansa Kertomuksen vaarat kohdistaa tapoihin, joilla tarinallisuutta ja yksilöiden kokemuskertomuksia hyödynnetään instrumentaalisesti eli pyrkien niiden avulla johonkin tiettyyn päämäärään. Pikemminkin kuin yksittäisiin tarinoihin tai niiden kertojiin kirjan huomio kohdistuu tarinatalouden logiikkaan ja kertomusbuumin todellisiin ja mahdollisiin seurauksiin. Tarinataloudella tarkoitetaan sitä huomiotalouden osaa, joka perustuu sosiaaliseen mediaan liittyvään näkyvyyden pääomaan. Tarinatalous pohjautuu yleisöjen ja asiakkaiden huomion tavoitteluun (usein yksilön kokemuksen) tarinallistamisen keinoin. Sitä luonnehtii myöhäismodernille järjestykselle tyypillinen identiteettien, bisneksen ja tiedonvälityksen välisten rajojen liudentuminen. Kertomusbuumiksi kirja kutsuu vuosituhannen vaihteessa yleistynyttä käsitystä tarinallisuuden positiivisesta ja välinearvosta. Buumin tausta paikannetaan moninaisiin 1900-luvun jälkipuoliskon liikkeisiin, trendeihin ja ilmiöihin alkaen self-help -kirjallisuudesta, 1960-ja 1970-luvun ihmisoikeusliikkeiden strategioista tieteen kerronnalliseen käänteeseen, sosiaaliseen mediaan ja startup-kulttuuriin.

Kirjan keskittyessä esittelemään näitä ilmiöitä monien esimerkkitapausten ja näkökulmatekstien kautta jää yksilö- ja kokemuskeskeisyyden ideologisten, poliittisten ja filosofisten juurien avaaminen ohuehkoksi. Kenties tämänkaltaista taustoitusta on tehty hankkeen muissa julkaisuissa. Metodologisilta lähtökohdiltaan kirja nojaa narratologiaan ja sen venäläisten formalistien fabula-sjuzhet-jaon pohjalta kehittyneeseen kertomuksen ja tarinan analyyttiseen erotteluun. Vaikka kirjan alkupuolella eron tekemisen tärkeys tuodaan esiin, en paikoin kyennyt hahmottamaan analyyttista eroa käsitteiden käytössä.

Kirjan alkupuolen Maria Mäkelän ja Laura Karttusen kirjoittamissa luvuissa avataan prosesseja, joissa yksilön henkilökohtainen kokemuskertomus muuttuu esimerkiksi yleisestä ja jopa todisteeksi (moraalisesta) normista niin sosiaalisen median kuin journalismin konteksteissa - ja usein niiden vuorovaikutuksessa. Teksteissä jäsennellään kiertäviä mallitarinoita ja niiden välittämiä moraliteetteja sekä pohditaan faktan ja fiktion (sekä kokemuksellisuuden ja asiasisällön) suhteita runsaiden esimerkkien valossa. Laura Karttusen artikkeli "Kokemuksellinen kertomuskäsitys" on esimerkillisen selkeä esitys projektin taustalla vaikuttavasta analyyttisestä tavasta ymmärtää kertomus. 
Totuudenjälkeistä politiikkaa sekä politiikan tarinallistumista ja henkilöitymistä käsittelevässä luvussa Ari-Elmeri Hyvönen ja Maria Mäkelä pohtivat faktan, fiktion ja mielipiteen suhdetta sekä niiden rooleja demokratian toteutumisen kannalta hyödyntämällä käsitettä piittaamaton puhe (careless speech) (ks. Hyvönen 2018). Piittaamaton puhe ei välitä faktoista, minkä lisäksi se murentaa poliittisen keskustelun ja eri mielipiteiden ilmaisun mahdollistavaa jaettua todellisuutta. Luvun lopussa Ville Hämäläinen käy keskustelua poliitikkojen kanssa, jotka avaavat kiinnostavasti (ja epäilemättä kiusallisesti) muun muassa Vihreiden viestintästrategian lähtökohtaista tarinallisuutta. Yksilöiden tarinoista elävää aktivismia ja \#metoo -liikettä käsittelevä Tytti Rantasen ja Taija Roihan artikkeli valottaa yhtäältä sitä, miten yksilötarinoista voi tulla uskottavia ja yksittäisen kokemuskertomuksen yläpuolelle nousevia todisteita vallitsevasta asiatilasta ja epätasa-arvoisista rakenteista. Toisaalta se pohtii oivaltavan kriittisesti myös sitä, miten kokemuskertomukset kaavamaistuvat herkästi, jolloin vain tietynlaiset näkökulmat tulevat kuulluiksi ja kerrotuiksi. Tämä taas voi johtaa huomiota pois alistavista rakenteista - liikkeen tavoitteiden kannalta paradoksaalisesti. Etenkin havainto "hiljaisuuden murtamisen" yksinkertaistavan troopin ja siihen kytkeytyvien sankaritarinoiden vaaroista muutoksen kuvauksen yhteydessä on erinomaisen tärkeä. Sinällään "hyvän asialla" olevat yksinkertaistukset voivat häivyttää näkyvistä positioiden, toiminnan ja osallisuuksien epämääräisiä ja harmaita alueita, jotka eivät ongelmitta asetu käsityksiimme "oikeanlaisesta" uhrista tai muutoksesta.

Johtuen kirjan luonteesta käytännöllisenä oppaana ja tietokirjana se ei tyydy ainoastaan esittelemään ja analysoimaan kertomusten käyttöä ja toimintaa, vaan tarjoaa konkreettisia ohjeita "parempia kertomuksia" ja vastuullista tarinankerrontaa varten: jokainen luku päättyy numeroituun vinkkilistaan, ja kirjan päättää lista yleisistä periaatteista, jotka "eivät ole kymmenen käskyä, vaan kymmenen ehdotusta" (s. 312) kertomusten kertomista ja tulkintaa varten.

\section{Kertomuksen keinojen, lajien ja todellisuuksien rajapintoja analysoiden}

Mikko T. Virtasen kirjoittaman johdantoartikkelin lisäksi Kertomuksen keinoin. Tarinallisuus mediassa ja tietokirjallisuudessa -kirja sisältää yksitoista artikkelia, jotka jakautuvat neljään lukuun. Luvuista kolme keskittyy tietokirjallisuuteen, yksi journalismiin. Pikemminkin kuin fokusoiden yksinomaan kertomukseen, teos avaa näkökulmia laajemminkin kerronnan keinoihin ja käytänteisiin. Sen lisäksi, että siinä analysoidaan kertomuksen rakenteellisia piirteitä laji- tai tekstikonteksteissa, kertomusta ja kerronnan keinoja tarkastellaan osana kulttuurista, historiallista ja sosiaalista toimintaa.

Osa kirjan artikkeleista sijoittuu selkeämmin kirjallisuustieteen, osa kielentutkimuksen alueille, "mutta pääasiassa liikutaan alojen välisellä yhteismaalla" (s. 9), kuten Virtanen toteaa johdannossa. Monissa teoksen artikkeleista pureudutaan kirjallisuuden lajien sekä (todellisuus)viittaavuuksien lomittumisen, rajapintojen ja niihin kytkeytyvien merkitysten analysointiin. Kirjaa voimakkaasti leimaavana näkökulmana on kertomustyyppien, kerronnan keinojen sekä esitystapojen analysointi suhteessa teoksen tai tekstin lajiin. Myös tietokirjallisuuden laaja kenttä hahmottuu artikkeleissa sen alalajien, kuten tietokirjoittamisen oppaiden (Pirjo Hiidenmaa), tiedettä popularisoivien teosten (Mikko T. Virtanen; Henri Satokangas; Elina Vitikka), matkakertomuksen (Ilona Lindh), surukirjallisuuden (Anna Hollsten), historiantutkimuksen (Jyrki Nummi) ja esseen (Päivi Koivisto) näkökulmista. 
Itselleni teoksen kiinnostavimpia artikkeleita ovat Sanna Nyqvistin "Kenen sanat ja tarinat?" ja Elina Vitikan "Minä tutkija, me ihmiset". Tekstit avaavat inspiroivia näkökulmia omistajuuden, tekijyyden ja tutkijan tekstiin konstruoidun aseman kysymyksiin. Nyqvistin artikkeli tarkastelee tietokirjallisuutta kaunokirjallisuuden lähteenä. Siinä analysoidaan tapauksia, joissa lainaamisen rajoista ja tavoista sekä lähteiden käytöstä on kiistelty julkisuudessa äärimmillään plagiointisyytösten kera. Erityisesti Nyqvist pureutuu syksyllä 2015 Ruotsissa käynnistyneeseen tapaukseen, jossa tietokirjailija Jan Bergman syytti kirjailija Jan Guillouta Ruotsin tiedusteluhistoriaa käsittelevän Secreterarklubben -tietokirjansa (2014) aihepiirin ja henkilöhahmojen varastamisesta tämän romaaniin Blå stjärnan (2015). Artikkeli analysoi tapausta kriittisesti tekijänoikeuslain, luovan työn etiikan ja julkisen retoriikan näkökulmista sekä nostaa esiin sen yhteyksiä vastaaviin julkisiin debatteihin. Teksti pohtii tekijyyteen ja omistajuuteen kytkeytyviä kysymyksiä sekä sepitteellisen ja referentiaalisen esityksen lajeja ja intertekstuaalisia suhteita tavalla, jonka relevanssi kulttuurien tutkimuksen parissa operoiville on ilmeinen. Elina Vitikan artikkeli analysoi monipuolisesti tekijään viittaavia ensimmäisen persoonan ilmauksia ja niiden merkityksiä Kari Enqvistin kosmologista tutkimusta popularisoivassa omaelämäkerrallisessa tietokirjassa Ensimmäinen sekunti: Silminnäkijän kertomus (2014). Vitikan analyysi tuo esiin näiden ilmausten monet funktiot aina teoksen ideaalilukijan hahmottelusta, me-ryhmän luomisesta ja tekijän asiantuntijaidentiteetin rakentamisesta lukijan vakuuttamiseen ja osallistamiseen.

Kirjan viimeinen, journalismia käsittelevä luku sisältää kaksi artikkelia. Maria Mäkelän ja Laura Karttusen teksti käsittelee tarinallista yksilöjournalismia pitkälti Kertomuksen vaarat -kirjan linjojen mukaisesti. Ralf Kauranen ja Olli Löytty sen sijaan tarkastelevat journalismiin pohjautuvaa ja sarjakuvan muodossa toteutettua narratiivista tietokirjaa pohtien tiedon välittämisen ja näyttämisen keinoja. Esimerkkinä he analysoivat Emmi Niemisen ja Johanna Vehkoon internetin naisvihasta kertovaa teosta Vihan ja inhon internet (2017). Kaurasen ja Löytyn rikas analyysi tarkastelee teosta moniäänisenä, -modaalisena ja -lajisena kokonaisuutena. He myös suhteuttavat analyysiään laajempiin käsityksiin sarjakuvasta representaationa. Analyysin pohjalta Vihan ja inhon internet tulkitaan sekä tiedollisesti (journalistinen tiedonvälitys) että poliittisesti (feministinen voimaannuttaminen) avoimen paikantuneeksi teokseksi, joka "sarjakuvan keinoin pyrkii vakuuttamaan lukijan esitettyjen tietojen oikeellisuudesta" (s. 333).

\section{Lopuksi}

Kertomuksen vaarat -kirjaan verrattuna Kertomuksen keinoin on muodoltaan perinteisempi tutkimusartikkelikokoelma. Siitä puuttuu edellisen paatos ja ohjelmallisuus, ja sen analyyttinen ote on tyynempää ja artikkelit laajempia. Kertomuksen keinoin esittelee myös laajemman lähestymistapojen kattauksen kertomuksen ja kerronnan keinojen analyysiin. Kertomuksen vaarat -kirja taas on onnistunut kristallisoimaan tutkimushankkeen tuloksia laajasti kiinnostavalla tavalla, jolle ei monia vertailukohtia löydy. Julistuksellisuuteen kallistuva ote sopii kertomuskriittiseksi oppaaksi nimetyn kirjan pirtaan, vaikka moniaineksisuuden, keskeisideoiden toiston ja lyhyen muodon suosimisen ohella se teki lukukokemuksestani hieman hektisen. Pääpointtien toisto epäilemättä kuitenkin tukee lukijan mielenkiinnon yllä pysymistä sekä tutkimuksen keskeisten havaintojen ymmärrettävyyttä ja vaikuttavuutta.

Kertomukseen ja kerronnan keinoihin keskittymisen ohella Kertomuksen vaarat ja Kertomuksen keinoin teoksia yhdistää se, että molemmat korostavat kriittisen lukutaidon tärkeyttä. 
Kirjat nostavat monipuolisesti esiin (tarinan)kerrontaan liittyviä eettisiä kysymyksiä, jotka ovat huomionarvoisia myös kulttuurien tutkimuksen alojen näkökulmasta. Suosittelen lämpimästi lukemaan teoksia rinnakkain. Yhdessä ne avaavat monipuolisen maiseman kertomuksen funktioihin ja vaaroihin nykykulttuurissa ja tutkimuksessa.

\section{Kirjallisuus}

Bergman, Jan. 2014. Secreterarklubben: C-byråns kvinnliga agenter under andra världskriget. Stockholm: Norstedts.

Enqvist, Kari. 2014. Ensimmäinen sekunti: Silminnäkijän kertomus. Helsinki: WSOY.

Guillou, Jan. 2015. Blå stjärnan: Det stora århundradet V. Stockholm: Piratförlaget.

Hyvönen, Ari-Elmeri. 2018. "Careless Speech. Conceptualizing Post-Truth Politics." New Perspectives 26(3): 1-25. https://doi.org/10.1177/2336825X1802600303

Nieminen, Emmi ja Johanna Vehkoo. 2017. Vihan ja inhon internet. Helsinki: Kosmos.

Ulla Savolainen on dosentti ja yliopistotutkija Helsingin yliopistossa, kulttuurien osastossa. Hän on kulttuurisen muistin, muistitiedon ja kerronnan tutkimukseen erikoistunut folkloristi, joka johtaa parhaillaan tutkimushanketta "Transnational Memory Cultures of Ingrian Finns: A Comparative Perspective on the Dynamics of Personal and Cultural Remembrance". 
(19) 